\title{
Investigation of MI/M4 Muscarinic Receptors in the Anterior Cingulate Cortex in Schizophrenia, Bipolar Disorder, and Major Depression Disorder
}

\author{
Zavitsanou Katerina*, $^{*}$, , Katsifis Andrew ${ }^{3}$, Mattner Filomena ${ }^{3}$ and Huang Xu-Feng ${ }^{2}$ \\ 'Neuroscience Institute of Schizophrenia and Allied Disorders (NISAD); '2Department of Biomedical Science, University of Wollongong, NSW, \\ Australia; ${ }^{3}$ Australia Nuclear Science and Technology Organization (ANSTO), NSW, Australia
}

\begin{abstract}
Abnormal cholinergic neurotransmission has been suggested to occur in psychiatric illness. Therefore, this study investigated cholinergic muscarinic receptors in the anterior cingulate cortex (ACC) of schizophrenia, bipolar disorder and major depression disorder $(n=15$ per group). We used quantitative autoradiography to measure $\left[{ }^{3} \mathrm{H}\right]$ pirenzepine binding to $\mathrm{MI}$ and $\mathrm{M} 4$ receptors. Brain tissue was obtained from the Stanley Foundation Neuropathology Consortium. $\left[{ }^{3} \mathrm{H}\right]$ pirenzepine binding was higher in superficial laminae $(\mathrm{I}-\mathrm{II})$ than in deep laminae $(\mathrm{III}-\mathrm{VI})$ of the ACC. There was a significant $24 \%$ reduction in the density of $\left[{ }^{3} \mathrm{H}\right]$ pirenzepine in the deep laminae and a significant $19 \%$ reduction in the upper laminae of the ACC in the schizophrenia group compared to the control group. There were no differences in $\left[{ }^{3} \mathrm{H}\right]$ pirenzepine binding in any laminae of the ACC in the bipolar or major depression groups compared with the control group, except for a trend towards decreased $\left[{ }^{3} \mathrm{H}\right]$ pirenzepine binding in subjects with major depression relative to control subjects. We also detected a significant effect of suicide on $\left[{ }^{3} \mathrm{H}\right]$ pirenzepine binding in the ACC in subjects who died as a result of suicide relative to those who did not, which was more evident in patients with schizophrenia. A significant effect of the onset of the disease was also observed that was more evident in patients with bipolar disorder. The study provides evidence of decreased muscarinic receptor density in the ACC in schizophrenia but no evidence for significant changes in these receptors in the bipolar and major depression groups. The changes observed in schizophrenia may contribute to dysfunctional ACC neural circuits.

Neuropsychopharmacology (2004) 29, 619-625, advance online publication, 17 December 2003; doi: I 0.1038/sj.npp. I 300367
\end{abstract}

Keywords: cingulate cortex; muscarinic receptors; schizophrenia; affective disorders; autoradiography; pirenzepine

\section{INTRODUCTION}

Evidence suggests that muscarinic acetylcholine receptors may play an important role in the neural mechanisms underlying the pathophysiology of mood disorders and schizophrenia. Considerable evidence suggests increased cholinergic neurotransmission in bipolar mania and major depression disorders (Thakore and Dinan, 1996; Dilsaver, 1986; Fritze, 1993). In addition, muscarinic receptorcoupled pertussis toxin-sensitive $G$ proteins have been suggested to be the molecular site for the antimanic therapeutic effects of antibipolar treatments (Avissar and Schreiber, 1991). Atypical antipsychotic drugs (eg cloza-

\footnotetext{
*Correspondence: Dr K Zavitsanou, Neuroscience Institute of Schizophrenia and Allied Disorders, Department of Biomedical Sciences, University of Wollongong, Northfields Avenue, NSW 2522, Australia, Tel: +61 242213199 , Fax: + 61 2 42214096,

E-mail: katerina_zavitsanou@uow.edu.au

Received 31 July 2003; revised 28 September 2003; accepted 07 November 2003

Online publication: II November 2003 at http://www.acnp.org/ citations/Npp I | | | 0303342/default.pdf
}

pine, olanzapine), which are among the most effective anti-schizophrenia medications available, have strong antimuscarinic properties (Raedler et al, 2000). Further, studies using post-mortem brain tissue suggest regionspecific changes to muscarinic receptors in schizophrenia. Early studies, using post-mortem tissue from schizophrenia patients, found increased M2/M4 receptor binding in the orbital frontal cortex and putamen (Owen et al, 1981; Watanabe et al, 1983) and decreased binding in frontal, parietal, and temporal cortices (Bennett et al, 1979). More recently, Dean et al (1996) and Crook et al (2000, 2001) found decreased M1/M4 receptor binding in the striatum, hippocampal formation, and prefrontal cortex in schizophrenia. Also, a deficit in cholinergic interneurons, as well as decreased binding to muscarinic M2/M4 receptors, has been suggested to occur in the striatum in schizophrenia (Holt et al, 1999; Crook et al, 1999).

The anterior cingulate cortex (ACC; Brodmann's area 24) is localized within a gyrus on the media surface of each hemisphere, bordering on the corpus callosum. Neuropathological changes have been reported in the ACC in 
bipolar disorder, major depression, and schizophrenia (see Knable et al, 2002, for a review). There is also evidence suggesting that the ACC might be an anatomical locus of a cholinergic deficiency in schizophrenia. It receives intense cholinergic innervation from a collection of cells in the basal forebrain, the anteromedial sector of the $\mathrm{Ch} 4$ cholinergic group of the nucleus basalis of Meynert (Mesulam, 1995). It is involved in functions (eg cognition, attention) that are modulated by acetylcholine and are deficient in schizophrenia (Hyde and Crook, 2001). Abnormalities in noncholinergic receptor systems (including glutamate, GABA, and serotonin) that are modulated by acetylcholine have been reported in the ACC in schizophrenia by our group (Zavitsanou and Huang, 2002; Zavitsanou et al, 2002) and others (Benes, 2000). Impairment in excitatory outflow activity of ACC pyramidal neurons has been suggested to occur in schizophrenia (Benes, 2000), and muscarinic receptors can regulate this activity (Hyde and Crook, 2001).

Muscarinic receptors of the M1/M4 subtype are localized postsynaptically and are the most abundant in the ACC (Gebhard et al, 1995; Mash et al, 1998). In the present study, we tested the hypothesis that muscarinic receptor density is altered in the ACC in schizophrenia. We used quantitative autoradiography and the muscarinic antagonist $\left[{ }^{3} \mathrm{H}\right]$ pirenzepine that binds selectively to M1 and M4 receptors (Flynn and Mash, 1993). Since considerable evidence suggests increased cholinergic neurotransmission in the pathophysiology of bipolar mania and major depression disorders (Thakore and Dinan, 1996; Dilsaver, 1986; Fritze, 1993), the present study also tested the hypothesis that muscarinic receptors are altered in the ACC of bipolar and major depression disorders.

\section{MATERIAL AND METHODS}

\section{Post-Mortem Brain Tissue}

Tissue was collected by the Stanley Foundation Brain Bank, which coded all specimens and screened the brains to exclude neuropathological abnormalities. A detailed description of this collection has been published recently (Torrey et al, 2000). The sample consisted of 60 cases (15 control, 15 schizophrenia, 15 bipolar, and 15 major depression cases). Demographic details are given in Table 1. Diagnoses of schizophrenia, bipolar disorder, and major depression were made according to the criteria of the fourth edition of the Diagnostic and Statistical Manual of Mental Disorders. Eight frozen sections were provided from the ACC (Brodmann's area 24) from each case. Inspection of Nissl stained sections indicated that the material comprised area $24 \mathrm{a}$ and $24 \mathrm{~b}$, together with a small contribution from area 32 and/or 33 and the subjacent callosal white matter (Vogt et al, 1995). Experiments were performed blind to all clinical details.

\section{Autoradiography}

All the sections were processed simultaneously to minimize experimental variance. The sections were preincubated for

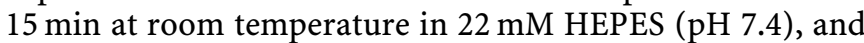
then incubated for $90 \mathrm{~min}$ at room temperature in the same buffer containing $10 \mathrm{nM}\left[{ }^{3} \mathrm{H}\right.$ ) pirenzepine (specific activity $79 \mathrm{Ci} / \mathrm{mmol}$, Amersham, UK). Two sections were incubated with $\left[{ }^{3} \mathrm{H}\right]$ pirenzepine and an additional two sections were incubated with $\left[{ }^{3} \mathrm{H}\right]$ pirenzepine plus $10 \mu \mathrm{M}$ of atropine to determine non-specific binding. The concentration of the

Table I Demographic Details and $\left[^{3} \mathrm{H}\right]$ pirenzepine Binding in the Anterior Cingulate Cortex of Subjects Obtained from the Stanley Foundation Brain Bank

\begin{tabular}{|c|c|c|c|c|}
\hline & Controls & Schizophrenia & Bipolar disorder & Major depression \\
\hline No. & 15 & 15 & 15 & 15 \\
\hline Age (years) & $48.07 \pm 2.75$ & $44.53 \pm 3.39$ & $42.43 \pm 3.03$ & $46.53 \pm 2.40$ \\
\hline Sex (females/males) & $6 / 9$ & $6 / 9$ & $6 / 9$ & $6 / 9$ \\
\hline Brain $\mathrm{pH}$ & $6.27 \pm 0.06$ & $6.16 \pm 0.07$ & $6.18 \pm 0.06$ & $6.18 \pm 0.59$ \\
\hline Post-mortem interval (h) & $23.73 \pm 2.57$ & $33.67 \pm 3.77$ & $32.53 \pm 4.16$ & $27.47 \pm 2.77$ \\
\hline Hemisphere (right/left) & $7 / 8$ & $6 / 9$ & $8 / 7$ & $6 / 6$ \\
\hline Suicides (yes/no) & $0 / 15$ & $4 / 11$ & $9 / 6$ & $7 / 8$ \\
\hline Age of onset of illness (years) & & $23.20 \pm 18.79$ & $21.47 \pm 2.16$ & $33.93 \pm 3.43$ \\
\hline Duration of illness(years) & & $21.33 \pm 2.95$ & $20.13 \pm 2.50$ & $12.67 \pm 2.86$ \\
\hline
\end{tabular}

Values are mean \pm SE.

a Lifetime quantity of fluphenazine or equivalent (mg). 
ligand was measured in $10 \mu \mathrm{l}$ aliquots taken from the incubation mixture. After incubation, the sections were rinsed three times ( $4 \mathrm{~min}$ each) in ice-cold buffer with a final dipping in ice-cold distilled water and air-dried. After the assay, sections were exposed to $\left[{ }^{3} \mathrm{H}\right]$ sensitive film (Amersham, UK) for 7 days. $\left[{ }^{3} \mathrm{H}\right]$ microscales from Amersham were used as standards.

\section{Quantitative Analysis of Autoradiographic Images}

Autoradiographs were developed at room temperature in Kodak X-ray developer $(4 \mathrm{~min})$ and exposed to cold tap water (15s), Kodak X-ray fixer (4 min), cold tap water (10 min), and room temperature air to dry. For the confirmation of anatomical structures, sections were stained with cresyl violet after the development of the autoradiographs. Section images on the film were then superimposed on the stained sections and observed under an Olympus BX50 microscope to determine the distribution of each ligand among the cortical layers.

Quantification analysis of the resulting autoradiographic images was performed by using a computer-assisted image analysis system (Multi Analyst, BIO-RAD, USA), connected to a GS-690 Imaging Densitometre. Since $\left[{ }^{3} \mathrm{H}\right]$ pirenzepine binding displayed different distribution among cortical layers, measurements were averaged from different representative compartments (upper and lower laminae) of the cortical gray matter (detailed in Results section). For each compartment, at least six measurements were randomly taken. Optical density measurements were converted into fmoles $\left[{ }^{3} \mathrm{H}\right]$ ligand per $\mathrm{mg}$ tissue equivalent (TE), according to the calibration curve obtained from the tritium standards.

\section{Statistical Analysis}

One-way analysis of variance (ANOVA) was used to compare the levels of radioligand binding in different ACC cortical compartments (upper and lower laminae) per study cohort. ANOVA, followed by least statistical significance (LSD) post hoc tests, was used to compare the mean age, post-mortem interval (PMI), onset of the disease, freezer storage time, and $\mathrm{pH}$ value between the four diagnostic groups.

For continuous descriptive variables (PMI, age, estimated lifetime exposure to neuroleptics, age of illness onset, illness duration, brain $\mathrm{pH}$, brain weight and freezer storage time), we sought significant Spearman's correlations for the abnormal radioligand binding. Three non-continuous descriptive variables (hemisphere, gender and suicide) were used as grouping variables with $t$-tests to evaluate their effects on abnormal radioligand binding.

Separate one-way analyses of covariance (ANCOVA), controlling for age, suicide, and PMI, were performed within each cortical compartment (upper and lower laminae). The LSD post hoc test was used for comparisons of the main effects of diagnosis on radioligand binding between the four groups. All tests were performed using the SPSS statistical package.

\section{RESULTS}

\section{Laminar Distribution of $\left[{ }^{3} \mathrm{H}\right]$ pirenzepine Binding in the ACC}

Specific binding of $\left[{ }^{3} \mathrm{H}\right]$ pirenzepine was observed in all cortical sections. Non-specific binding was $0 \%$ (background levels). The laminar distribution of $\left[{ }^{3} \mathrm{H}\right]$ pirenzepine binding to muscarinic M1/M4 receptors in the ACC is illustrated in Figure 1.

Binding sites labelled by the three ligands appeared to have differential distribution among the layers of the ACC. The principal laminar patterns of $\left[{ }^{3} \mathrm{H}\right]$ pirenzepine binding were similar among the different diagnostic groups. A higher density of $\left[{ }^{3} \mathrm{H}\right]$ pirenzepine binding was observed within the superficial (upper) laminae of ACC compared with the deeper (lower) laminae (schizophrenia: upper $104.28 \pm 11.21 \mathrm{fmol} / \mathrm{mg}$ TE, lower $72.72 \pm 7.79 \mathrm{fmol} / \mathrm{mg} \mathrm{TE}$, $\mathrm{F}=5.35, \quad \mathrm{df}=1,28, \quad p=0.028 ;$ control: upper $129.37 \pm$ $7.58 \mathrm{fmol} / \mathrm{mg} \mathrm{TE}$, lower $96.21 \pm 4.57 \mathrm{fmol} / \mathrm{mg} \mathrm{TE}, \mathrm{F}=14.04$, $\mathrm{df}=1,28, p=0.001$; depression: upper $119.38 \pm 11.72 \mathrm{fmol} /$ $\mathrm{mg} \mathrm{TE}$, lower $84.02 \pm 8.10 \mathrm{fmol} / \mathrm{mg} \mathrm{TE}, \mathrm{F}=6.16$, $\mathrm{df}=1,28$, $p=0.019$; bipolar: upper $136.44 \pm 12.08 \mathrm{fmol} / \mathrm{mg} \mathrm{TE}$, lower $96.17 \pm 8.19 \mathrm{fmol} / \mathrm{mg} \mathrm{TE}, \mathrm{F}=7.61, \mathrm{df}=1,28, p=0.010$. Inspection of Nissl staining sections indicated that upper layers correspond to layers I-II and lower layers correspond to layers III-VI.

\section{Effects of Continuous and Non-continuous Confounding Variables}

The mean age, PMI, pH, and brain weight did not differ between the groups studied. One-way ANOVA revealed significant differences in freezer storage time between the four diagnostic groups $(\mathrm{F}=5.353, \mathrm{df}=3,56, p=0.003)$. More specifically, the mean freezer time was significantly shorter in the control group in comparison to the bipolar and schizophrenia groups $(p=0.002$ and 0.002 , respectively), whereas it was significantly longer in the bipolar and

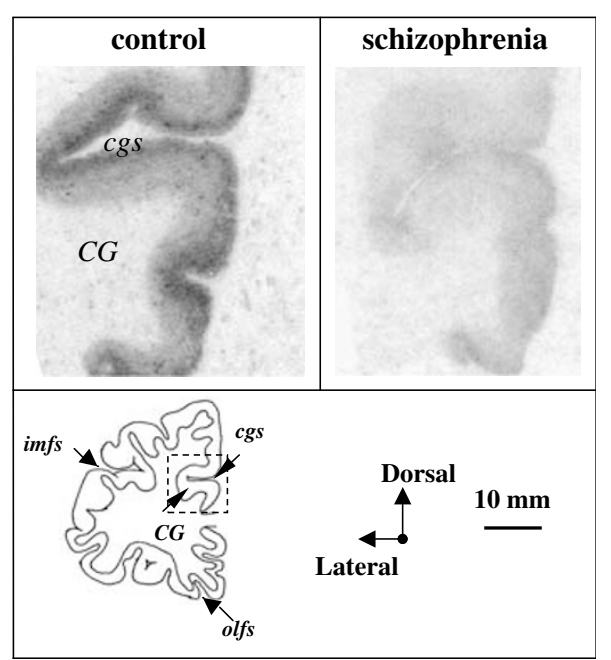

Figure I $\left[{ }^{3} \mathrm{H}\right]$ pirenzepine binding in the anterior cingulate cortex of one control and one schizophrenia case. CG: cingulate gyrus; cgs: cingulate sulcus; imfs: intermediate frontal sulcus; olfs: olfactory sulcus. 
Table 2 : Spearman's Rank Order Correlations for Continuous Variables and t-tests for Non-continuous Variables on [ ${ }^{3} \mathrm{H}$ ]pirenzepine Binding in Layers I-II and III-VI in the Anterior Cingulate Cortex of Subjects Studied from the Stanley Foundation Brain Bank

\begin{tabular}{|c|c|c|c|c|c|c|}
\hline Diagnosticgroup & Variable & Layers & $t$ & df & $\rho$ & $p$ \\
\hline All & Suicide & $1-I \mid$ & 2.15 & 58 & & 0.036 \\
\hline All & Suicide & $\| I I-\mathrm{VI}$ & 1.69 & 58 & & 0.097 \\
\hline All & Onset & $|-| \mid$ & & & -0.327 & 0.029 \\
\hline All & Onset & III-VI & & & -0.287 & 0.055 \\
\hline Control & Age & $|-| \mid$ & & & -0.786 & 0.001 \\
\hline Schizophrenia & Suicide & $|-| \mid$ & 4.298 & 13 & & 0.001 \\
\hline Schizophrenia & Suicide & III-VI & 4.364 & 13 & & 0.001 \\
\hline Depression & PMI & $|-| \mid$ & & & -0.464 & 0.082 \\
\hline Depression & PMI & III-VI & & & -0.421 & 0.018 \\
\hline Bipolar & $\mathrm{pH}$ & $|-| \mid$ & & & 0.524 & 0.045 \\
\hline Bipolar & Onset & $1-I \mid$ & & & -0.531 & 0.042 \\
\hline Bipolar & Onset & $|I I-V|$ & & & -0.558 & 0.031 \\
\hline
\end{tabular}

Only significant or of approximating significance variables are presented.

schizophrenia groups in comparison to major depression group ( $p=0.035$ and 0.034 , respectively; see Table 1 ).

We examined the effects of continuous and noncontinuous confounding variances on $\left[{ }^{3} \mathrm{H}\right]$ pirenzepine binding including all four diagnostic groups and within each group separately. Spearman's rank order correlations for continuous variables and $t$-tests for non-continuous variables are presented in Table 2.

Overall, $\left[{ }^{3} \mathrm{H}\right]$ pirenzepine binding in the upper layers was higher in cases who had committed suicide in comparison to cases who did not $(138.59 \pm 11.39 \mathrm{fmol} / \mathrm{mg} \mathrm{TE}, n=20 \mathrm{vs}$ $114.26 \pm 5.64 \mathrm{fmol} / \mathrm{mg} \quad \mathrm{TE}, \quad n=40, \quad t=2.152, \quad \mathrm{df}=58$, $p=0.036) .\left[{ }^{3} \mathrm{H}\right]$ pirenzepine binding in the lower layers of ACC was higher in cases who had committed suicide, but this difference was not statistically significant $(96.17 \pm 7.87$ vs $82.83 \pm 3.94 \mathrm{fmol} / \mathrm{mg}$ TE, $t=1.687, \mathrm{df}=58, p=0.097)$. $\left[{ }^{3} \mathrm{H}\right]$ pirenzepine binding was affected by the onset of the disease in the upper layers $(r=-0.327, p=0.029)$ with a borderline significance in the lower layers $(r=-0.287$, $p=0.055)$. $\left[{ }^{3} \mathrm{H}\right]$ pirenzepine binding was unaffected by the side of the brain, gender, age, PMI and final dose of antipsychotic medication, duration of the illness, $\mathrm{pH}$, weight of the brain, and days of storage in both upper and lower layers (data not shown).

In the control group there was a significant negative correlation between age and $\left[{ }^{3} \mathrm{H}\right]$ pirenzepine binding in both upper and lower layers (upper $r=-0.786, p=0.001$; lower $r=-0.560, p=0.030$ ). There was a significant correlation between $\left[{ }^{3} \mathrm{H}\right]$ pirenzepine binding and weight of the brain in the lower layers but not in the upper layers (lower $r=-0.547, p=0.035$; upper $r=-0.351, p=0.2$ ). $\left[{ }^{3} \mathrm{H}\right]$ pirenzepine binding was unaffected by all the other continuous and non-continuous variables for both upper and lower layers in the control group.

In the schizophrenia group, $\left[{ }^{3} \mathrm{H}\right]$ pirenzepine binding in the upper layers was higher in cases who had committed suicide, in comparison to cases who did not $(157.59 \pm 13.56 \mathrm{fmol} / \mathrm{mg}$ TE, $n=4$ vs $84.89 \pm 8.89 \mathrm{fmol} / \mathrm{mg}$ TE, $n=11, t=4.298, \mathrm{df}=13, p=0.001) .\left[{ }^{3} \mathrm{H}\right]$ pirenzepine binding in the lower layers was higher in cases who had committed suicide, in comparison to cases who did not $(109.97 \pm 9.41$ vs $59.17 \pm 6.10 \mathrm{fmol} / \mathrm{mg}$ TE, $t=4.367, \mathrm{df}=13$, $p=0.001$; Figure 2). $\left.{ }^{3} \mathrm{H}\right]$ pirenzepine binding was unaffected by gender, side of the brain, age PMI, $\mathrm{pH}$, exposure to neuroleptics, onset, duration, weight, and days of storage.

In the depression group, there was a trend toward significance of gender on $\left.{ }^{3} \mathrm{H}\right]$ pirenzepine binding in the upper layers $(t=-1.834, \mathrm{df}=13, p=0.090)$, but not in the lower layers $(t=-1.695, \mathrm{df}=13, p=0.114)$, and a tread toward significant correlation between age and $\left[{ }^{3} \mathrm{H}\right]$ pirenzepine binding in the lower layers of ACC $(r=0.476$, $p=0.073)$, but not in the upper layers $(r=0.388, p=0.153)$. There was also a trend towards significance for PMI in the upper layers $(r=-0.464, p=0.082)$, but not in the lower layers $(r=-0.421, p=0.118) .\left[{ }^{3} \mathrm{H}\right]$ pirenzepine binding in the depression group appeared to be affected by duration of illness in the upper layers with a trend towards significance in the lower layers (upper $r=0.621, p=0.014$; lower $r=0.510, p=0.052)$. $\left[{ }^{3} \mathrm{H}\right]$ pirenzepine binding was unaffected by all the other continuous and non-continuous parameters.

In the bipolar group, there was a significant correlation between onset of the disease and $\left[{ }^{3} \mathrm{H}\right]$ pirenzepine binding in upper $(r=-0.531, p=0.042)$ and lower layers $(r=-0.558$, 


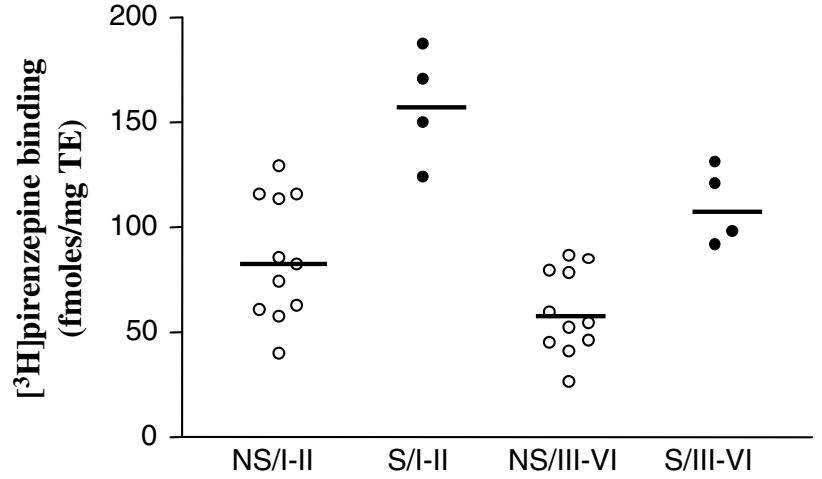

Figure 2 Scatter plot of $\left[{ }^{3} H\right]$ pirenzepine binding in the upper $(I-I I)$ and lower (III-VI) laminae of anterior cingulate cortex in schizophrenia cases who committed suicide (S, dark circles) and in nonsuicidal cases (NS, open circles).

$p=0.031)$ and a significant correlation between $\mathrm{pH}$ and $\left[{ }^{3} \mathrm{H}\right]$ pirenzepine binding in the upper layers $(r=0.524$, $p=0.045)$ but not the lower layers $(r=0.431, p=0.109)$. $\left[{ }^{3} \mathrm{H}\right]$ pirenzepine binding was unaffected by gender, suicide, side of the brain, and medication.

\section{Disease-related Effects on $\left[{ }^{3} \mathrm{H}\right]$ pirenzepine Binding in the ACC}

Levels of $\left[{ }^{3} \mathrm{H}\right]$ pirenzepine binding in the upper and lower layers of the ACC in the four diagnostic groups are presented in Table 1 and Figure 3.

There was a main effect of diagnosis on $\left[{ }^{3} \mathrm{H}\right]$ pirenzepine binding in the lower layers of the ACC $(\mathrm{F}=2.902, \mathrm{df}=3$, $p=0.043)$. A main effect of suicide on $\left[{ }^{3} \mathrm{H}\right]$ pirenzepine binding in the lower layers of ACC was also observed $(\mathrm{F}=4.994, \mathrm{df}=1, p=0.030)$. Post hoc analysis indicated that these main effects were due to the patients with schizophrenia having $24 \%$ lower levels of $\left[{ }^{3} \mathrm{H}\right]$ pirenzepine binding than the control group $(p=0.009)$, and patients with major depression having lower levels of $\left[{ }^{3} \mathrm{H}\right]$ pirenzepine binding than the control group $(p=0.05)$. There was a main effect of suicide on $\left[{ }^{3} \mathrm{H}\right]$ pirenzepine binding in the upper layers of ACC $(\mathrm{F}=4.994, \mathrm{df}=1, p=0.030$; Figure 3$)$ but no effect of diagnosis on $\left[{ }^{3} \mathrm{H}\right]$ pirenzepine binding in the upper layers of ACC $(\mathrm{F}=1.857, \mathrm{df}=3, p=0.148)$. Post hoc analysis indicated that this main effect was due to patients with schizophrenia having $19 \%$ lower levels of $\left[{ }^{3} \mathrm{H}\right]$ pirenzepine binding than the control group $(p=0.037)$.

\section{DISCUSSION}

The present study investigated the binding of the muscarinic receptor antagonist $\left[{ }^{3} \mathrm{H}\right]$ pirenzepine in the ACC of subjects with specific psychiatric diagnoses. This antagonist has been shown to possess the highest affinity for M1 receptors, but also relatively high affinity for M4 receptors (Buckley et al, 1989; Flynn and Mash, 1993). More specifically, $10 \mathrm{nM}\left[{ }^{3} \mathrm{H}\right.$ ]pirenzepine (the concentration of ligand used in the present study) labels $62.5 \%$ of M1 receptors and $18.5 \%$ of M4 receptors (Flynn and Mash, 1993). Therefore, this study provides information about the distribution and density of M1/M4 muscarinic receptors in
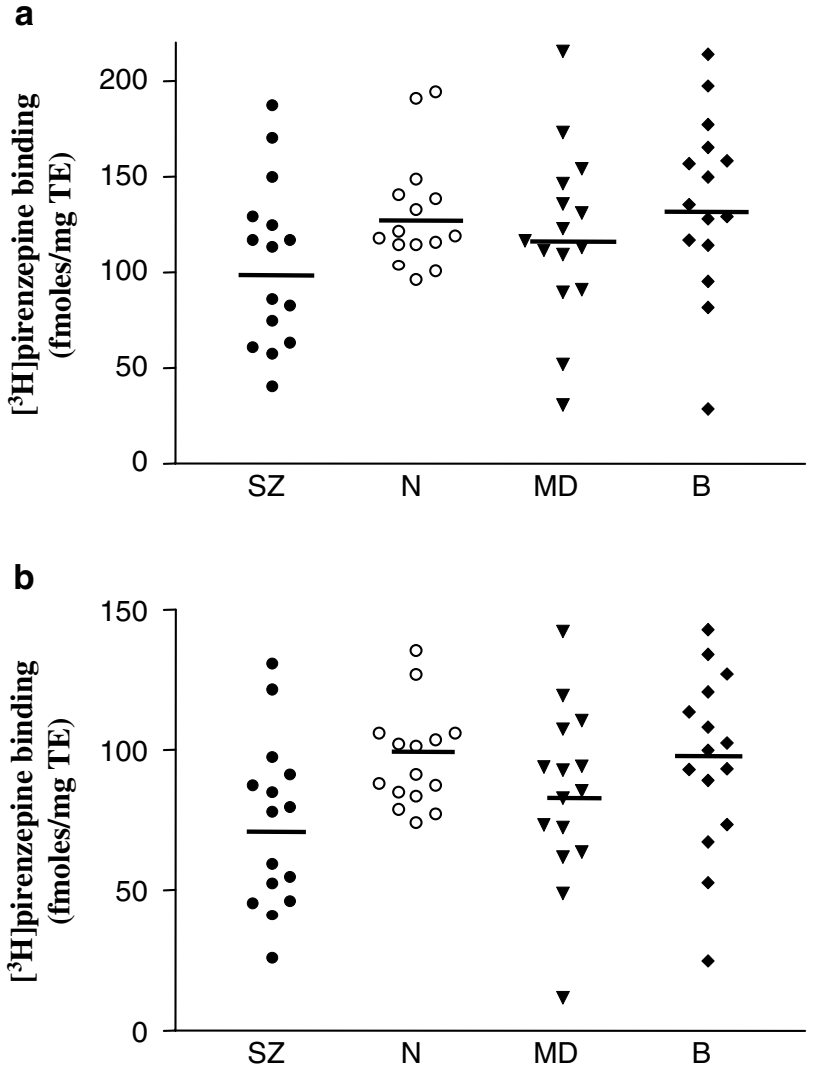

Figure 3 Scatter plot of $\left.{ }^{3} \mathrm{H}\right]$ pirenzepine binding in the upper (a) and lower (b) layers in the anterior cingulate cortex of schizophrenia (SZ), control (N), major depression (MD), and bipolar (B) groups.

the ACC of patients with schizophrenia, bipolar, and major depression as well as normal controls. We observed a higher density of M1/M4 receptors in the upper laminae compared to lower laminae in all groups studied. This characteristic cortical lamination pattern of M1/M4 receptors has been previously described (Piggott et al, 2002).

Although considerable evidence suggests abnormal cholinergic neurotransmission in the pathophysiology of bipolar mania and major depression, the results from this study do not support this notion, with no significant difference of M1/M4 receptor density observed between bipolar, major depression, and controls. In the depression group, muscarinic receptor density appeared to be affected by the duration of the illness, as the longer the duration of the illness, the higher the receptor density. In the bipolar group, there was a significant negative correlation between the density of receptors and the onset of the disease, suggesting that the earlier the age at onset, the lower the number of receptors. This may indicate that a younger age of onset of bipolar disorder is a factor affecting negatively on M1/M4 receptors in the ACC.

In this study, schizophrenia patients who had committed suicide had a higher density of M1/M4 receptors in the ACC than patients who died from other causes. A previous study suggested a $47 \%$ elevation of muscarinic receptors, in frontal cortical areas from cases who had committed suicide, compared to cases who did not (Meyerson et al, 1982). It is known that among patients with schizophrenia and schizoaffective disorders, as many as $40 \%$ attempt 
suicide at some stage in their lives and approximately $10 \%$ die from suicide (Meltzer and Okayli, 1995). The relationship between depression and suicide is unclear. In this study, no significant differences were observed between suicide and nonsuicide victims in both bipolar and major depression groups. Although the incidence of clinical depression in suicides is well documented, a statistical collation of such studies revealed that $12-64 \%$ of suicide victims were previously diagnosed as clinically depressed (Whitlock, 1977). Therefore, although suicide is often a consequence of depression, it seems possible that the muscarinic receptor alterations observed in the schizophrenia cases who committed suicide in this study, may not be exclusively associated with depression but with more complex neurochemical interactions associated with other pathophysiological states of the disease. Future studies that examine neurotransmitter receptor abnormalities in schizophrenia should therefore take into account patient's histories regarding suicidal behavior. Nevertheless, further studies, with larger numbers of schizophrenia cases who committed suicide, are required to delineate the relationship of muscarinic receptors to schizophrenia and suicide.

The present study revealed a significant decrease in M1/ M4 receptor density in both upper and lower layers in the schizophrenia group as compared to the control group. In agreement with our results, Dean et al (1996) and Crook et al $(2000,2001)$ found decreased $\left[{ }^{3} \mathrm{H}\right]$ pirenzepine binding to muscarinic M1/M4 receptors in the striatum, hippocampal formation, and prefrontal cortex in schizophrenia patients. A potential confounding factor in all studies in schizophrenia is the possible effects of antipsychotic medication. In the present study, the decrease in M1/M4 muscarinic receptor binding does not seem to be secondary to previous antipsychotic medication exposure since we found no correlation between $\left[{ }^{3} \mathrm{H}\right]$ pirenzepine binding and final recorded antipsychotic drug dose in the schizophrenia group. In addition, animal studies suggest that typical or atypical antipsychotic drugs tended to increase or have no effect on the density of $\left[{ }^{3} \mathrm{H}\right]$ pirenzepine-labelled receptors in rat frontal cortex (Crook et al, 2001).

Recent studies support abnormal neural circuitry in the ACC in schizophrenia. Studies by Francine Benes have indicated a loss of interneurons and increased $\mathrm{GABA}_{\mathrm{A}}$ receptor densities in the upper layers of the ACC in schizophrenia (see Benes, 2000 for a review). We have recently reported increased glutamate NMDA and AMPA receptor densities and decreased serotonin $5 \mathrm{HT}_{2 \mathrm{~A}}$ receptors in the ACC of schizophrenia (Zavitsanou et al, 2002; Zavitsanou and Huang, 2002). Importantly, all these systems are modulated by acetylcholine. The topographic co-occurance of cholinergic and other neurotransmitter receptor changes may signify important functional interactions in the ACC in schizophrenia. Further studies, combining neuroanatomical and binding techniques, are required to delineate these interactions as well as the relationship between cholinergic and other receptor system abnormalities in the ACC in schizophrenia.

The present study provides support for the presence of a deficit in M1/M4 receptors in the ACC in schizophrenia. The ACC asserts a fundamental role in normal cognition and controls the attention system that appears to function abnormally in schizophrenia (Posner et al, 1988). Since acetylcholine plays an important role in various domains of cognition including attention, it seems reasonable to suggest that changes in the muscarinic receptor system in the ACC in schizophrenia may be involved in the pathology of the disorder, particularly in relation to attentional and cognitive deficits. Most of the atypical antipsychotic drugs (eg clozapine, olanzapine) used for the treatment of both positive and negative symptoms of schizophrenia with less incidence of extrapyramidal side effects have been shown to possess muscarinic antagonistic properties (Raedler et al, 2000). Therefore, abnormalities in the muscarinic receptor system in the ACC in schizophrenia may also be involved in the pharmacotherapy of the disease.

\section{ACKNOWLEDGEMENTS}

This work was supported by an Australian Institute of Nuclear Science and Engineering (AINSIE) award to KZ and the Neuroscience Institute of Schizophrenia and Allied Disorders (NISAD; http://www.nisad.org.au), which is supported by infrastructure funding from NSW Health. We wish to thank Ms Kelly Newell for assistance on the day of the experiment. Post-mortem brain tissue was kindly donated by the Stanley Foundation Brain bank courtesy of Drs Michael Knable, E Fuller Torrey, Maree J Webster, and Robert Yolken.

\section{REFERENCES}

Avissar S, Schreiber G (1991). The involvement of guanine nucleotide binding proteins in the pathogenesis and treatment of affective disorders. Biol Psychiatry 31: 435-459.

Benes FM (2000). Emerging principles of altered neural circuitry in schizophrenia. Brain Res Rev 31: 251-269.

Bennett P, Enna SJ, Bylund DB, Gillin C, Wyatt RJ, Snyder SH (1979). Neurotransmitter receptors in frontal cortex in schizophrenia. Arch Gen Psychiatry 36: 927-934.

Buckley NJ, Bonner TI, Brann MR (1989). Antagonist binding properties of five cloned muscarinic receptors expressed in CHO-K1 cells. Mol Pharmacol 35: 469-476.

Crook JM, Dean B, Pavey G, Copolov D (1999). The binding of $\left[{ }^{3} \mathrm{H}\right] \mathrm{AF}-\mathrm{DX} 384$ is reduced in the caudate-putamen of subjects with schizophrenia. Life Sci 64: 1761-1771.

Crook JM, Tomaskovic-Crook E, Copolov DL, Dean B (2000). Decreased muscarinic receptor binding in subjects with schizophrenia: a study of the human hippocampal formation. Biol Psychol 48: 381-388.

Crook JM, Tomaskovic-Crook E, Copolov DL, Dean B (2001). Decreased muscarinic receptor binding in prefrontal cortex from subjects with schizophrenia: a study of Brodmann's areas 8,9 , 10, and 46, and the effects of neuroleptic drug treatment. Am J Psychiatry 158: 918-925.

Dean B, Crook JM, Oeskin K, Hill C, Keks H, Copolov DL (1996). The density of muscarinic M1 receptors is decreased in the caudate-putamen of subjects with schizophrenia. Mol Psychiatry 1: $54-58$.

Dilsaver SC (1986). Cholinergic mechanisms in depression. Brain Res Rev 11: 285-316.

Flynn DD, Mash DC (1993). Distinct kinetic binding properties of $\mathrm{N}-\left[{ }^{3} \mathrm{H}\right]$-methylscopolamine afford differential labelling and localization of M1, M2 and M3 muscarinic receptor subtypes in primate brain. Synapse 14: 283-296.

Fritze J (1993). The adrenergic-cholinergic imbalance hypothesis of depression: a review and a perspective. Rev Neurosci 4: 63-93. 
Gebhard R, Zilles K, Schleicher A, Everitt BJ, Robbins TW, Divac I (1995). Parcellation of the frontal cortex of the new world monkey Callithrix jacchus by eight neurotransmitter-binding sites. Anat Embryol 191: 509-517.

Holt DJ, Herman MM, Hyde TM, Kleinman JE, Sinton CM, German DC et al (1999). Evidence for a deficit in cholinergic interneurons in the striatum in schizophrenia. Neuroscience 94: 21-31.

Hyde TM, Crook JM (2001). Cholinergic systems and schizophrenia: primary pathology or epiphenomena? J Chem Neuroanat 22: 53-63.

Knable MB, Barci BM, Bartko JJ, Webster MJ, Torrey EF (2002). Abnormalities of the cingulate gyrus in bipolar disorder and other severe psychiatric illnesses: postmortem findings from the Stanley Foundation Neuropathology Consortium and literature review. Clin Neurosci Res 2: 171-181.

Mash DC, White WF, Mesulam MM (1998). Distribution of muscarinic receptor subtypes within architectonic subregions of the primate cerebral cortex. J Comp Neurol 278: 265-274.

Meltzer HY, Okayli G (1995). Reduction of suicidality during clozapine treatment of neuroleptic resistance schizophrenia: impact on risk-benefit assessment. Am J Psychiatry 152: 183-190.

Mesulam MM (1995). The cholinergic contribution to neuromodulation in the cerebral cortex. Semin Neurosci 7: 297-307.

Meyerson LR, Wennogle LP, Abel MS, Coupet J, Lippa AS, Rauh CE et al (1982). Human brain receptor alterations in suicide victims. Pharm Biochem Behav 17: 159-163.

Owen F, Cross AJ, Lofihouse R, Plulter M (1981). Neurotransmitter receptors in brain in schizophrenia. Acta Psychiatry Scand 3: 20-27.

Piggott M, Owens J, O' Brien J, Paling S, Wyper D, Fenwick J et al (2002). Comparative distribution of binding of the muscarinic receptor ligands pirenzepine, AF-DX 384, (R,R)-IQNQ and (R,S)-I)QNB to human brain. J Chem Neuroanat 24: 211-223.

Posner MI, Early TS, Reisman E, Pardo PJ, Dhawan M (1988). Asymmetries in hemispheric control of attention in schizophrenia. Arch Gen Psychiatry 45: 814-821.

Raedler TJ, Knable MB, Jones DW, Lafargue T, Urbina RA Egan MF, Pickar D et al (2000). In vivo olanzapine occupancy of muscarinic acetylcholine receptors in patients with schizophrenia. Neuropsychopharmacology 23: 56-68.

Thakore JH, Dinan TG (1996). Neuroendocrine abnormalities in bipolar mania and major depressive illness. Eur Psychiatry 11(Suppl 4): 304s.

Torrey EF, Webster M, Knable M, Johnston N, Yolken RH (2000). The stanley foundation brain collection and neuropathology consortium. Schizophr Res 44: 151-155.

Vogt BA, Nimchinsky EA, Vogt LJ, Hof PR (1995). Human cingulate cortex: surface features, flat maps and cytoarchitecture. J Comp Neurol 359: 490-506.

Watanabe S, Nishikawa T, Takashima M, Toru M (1983). Increased muscarinic cholinergic receptors in prefrontal cortices of medicated schizophrenics. Life Sci 33: 2187-2196.

Whitlock FA (1977). Depression and suicide. In: Burrows GD (ed). Handbook of Studies on Depression. Excerpta Medica: Amsterdam, 379-403.

Zavitsanou K, Huang XF (2002). Decreased $\left[{ }^{3} \mathrm{H}\right]$ spiperone binding in the anterior cingulate cortex of schizophrenia patients: an autoradiographic study. Neuroscience 109: 709-716.

Zavitsanou K, Ward P, Huang XF (2002). Selective alterations in ionotropic glutamate receptors in the anterior cingulate cortex in schizophrenia. Neuropsychopharmacology 27: 826-833. 